\title{
Kinetic Studies on Fermentative Production of Biofuel from Synthesis Gas Using Clostridium ljungdahlii
}

\author{
Maedeh Mohammadi, ${ }^{1}$ Abdul Rahman Mohamed, ${ }^{2}$ Ghasem D. Najafpour, ${ }^{1}$ \\ Habibollah Younesi, ${ }^{3}$ and Mohamad Hekarl Uzir $^{2}$ \\ ${ }^{1}$ Faculty of Chemical Engineering, Babol Noushirvani University of Technology, Babol 47148, Iran \\ ${ }^{2}$ Low Carbon Economy (LCE) Research Group, School of Chemical Engineering, Engineering Campus, \\ Universiti Sains Malaysia, 14300 Nibong Tebal, Penang, Malaysia \\ ${ }^{3}$ Department of Environmental Science, Faculty of Natural Resources and Marine Science, \\ Tarbiat Modares University, Nour 46414, Iran \\ Correspondence should be addressed to Abdul Rahman Mohamed; chrahman@eng.usm.my \\ and Ghasem D. Najafpour; najafpour@nit.ac.ir
}

Received 6 August 2013; Accepted 17 December 2013; Published 30 January 2014

Academic Editors: J. E. Barboza-Corona, S. Menoret, D. Pant, and L. Pochini

\begin{abstract}
Copyright (C) 2014 Maedeh Mohammadi et al. This is an open access article distributed under the Creative Commons Attribution License, which permits unrestricted use, distribution, and reproduction in any medium, provided the original work is properly cited.

The intrinsic growth, substrate uptake, and product formation biokinetic parameters were obtained for the anaerobic bacterium, Clostridium ljungdahlii, grown on synthesis gas in various pressurized batch bioreactors. A dual-substrate growth kinetic model using Luong for $\mathrm{CO}$ and Monod for $\mathrm{H}_{2}$ was used to describe the growth kinetics of the bacterium on these substrates. The maximum specific growth rate $\left(\mu_{\max }=0.195 \mathrm{~h}^{-1}\right)$ and Monod constants for $\mathrm{CO}\left(K_{s, \mathrm{CO}}=0.855 \mathrm{~atm}\right)$ and $\mathrm{H}_{2}\left(K_{s, \mathrm{H}_{2}}=0.412\right.$ atm $)$ were obtained. This model also accommodated the CO inhibitory effects on cell growth at high CO partial pressures, where no growth was apparent at high dissolved CO tensions $\left(P_{\mathrm{CO}}^{*}>0.743 \mathrm{~atm}\right)$. The Volterra model, Andrews, and modified Gompertz were, respectively, adopted to describe the cell growth, substrate uptake rate, and product formation. The maximum specific CO uptake rate $\left(q_{\max }=\right.$ $\left.34.364 \mathrm{mmol} / \mathrm{g}_{\text {cell }} / \mathrm{h}\right), \mathrm{CO}$ inhibition constant $\left(K_{I}=0.601 \mathrm{~atm}\right)$, and maximum rate of ethanol $\left(R_{\max }=0.172 \mathrm{mmol} / \mathrm{L} / \mathrm{h}\right.$ at $P_{\mathrm{CO}}=$ $0.598 \mathrm{~atm})$ and acetate $\left(R_{\max }=0.096 \mathrm{mmol} / \mathrm{L} / \mathrm{h}\right.$ at $\left.P_{\mathrm{CO}}=0.539 \mathrm{~atm}\right)$ production were determined from the applied models.
\end{abstract}

\section{Introduction}

The production of fuels and high value chemicals from synthesis gas has become an intriguing target, since the beginning of the 20th century. However, most of the developments and explorations in this area have been concentrated on the deployment of metal-based catalytic processes. Recently, attention has been turned towards the conversion of synthesis gas to biofuels and biochemicals through the microbial routes due to the advantages offered by microbes as biocatalysts over metal-based catalysts [1]. Fermentation of synthesis gas to produce second-generation biofuels would likely be an option to address part of the debates over production of fuels from food crops. Despite recent research and endeavors, fermentation of synthesis gas to biofuels is still a relatively immature technology to be demonstrated at a commercial scale and various technical and economical challenges should be obviated for its future commercial deployments [2].

Clostridium ljungdahlii is a strictly anaerobic acetogen known for its ability to grow autotrophically on synthesis gas constituents and ferment them to ethanol and acetate [3]. The bacterium catalyzes a Fischer-Tropsch type reaction under a mild condition of pressure and temperature to produce fuel and chemical. The overall pathway reaction which forms acetate from $\mathrm{CO}$ as well as $\mathrm{H}_{2} / \mathrm{CO}_{2}$ has been established for many acetogens [4]:

$$
\begin{gathered}
4 \mathrm{CO}+2 \mathrm{H}_{2} \mathrm{O} \longrightarrow \mathrm{CH}_{3} \mathrm{COOH}+2 \mathrm{CO}_{2} \\
2 \mathrm{CO}_{2}+4 \mathrm{H}_{2} \longrightarrow \mathrm{CH}_{3} \mathrm{COOH}+2 \mathrm{H}_{2} \mathrm{O}
\end{gathered}
$$

The stoichiometries for ethanol formation have not been determined due to the lack of autotrophic ethanologenic 
organisms. However, from a similarity point of view with respect to the reactions established for acetate formation, the following reactions have been proposed [4]:

$$
\begin{aligned}
& 6 \mathrm{CO}+3 \mathrm{H}_{2} \mathrm{O} \longrightarrow \mathrm{C}_{2} \mathrm{H}_{5} \mathrm{OH}+4 \mathrm{CO}_{2} \\
& 2 \mathrm{CO}_{2}+6 \mathrm{H}_{2} \longrightarrow \mathrm{C}_{2} \mathrm{H}_{5} \mathrm{OH}+3 \mathrm{H}_{2} \mathrm{O}
\end{aligned}
$$

In the above reactions, the reducing equivalents are served by $\mathrm{CO}$ and $\mathrm{H}_{2}$ and the stoichiometric coefficients are identical for these reduced species [5].

The aim of this study was to determine the intrinsic reaction and biokinetic parameters for $C$. ljungdahlii grown on $\mathrm{CO}$ and $\mathrm{H}_{2}$ at various initial gas pressures. It is well understood that the microbial growth and product distribution of microorganism during gas fermentation can be significantly affected by the partial pressure of the gas components, as the enzyme involved in the metabolic pathway of the organism is sensitive to substrate exposure [6]. In most studies conducted so far, the composition of gas was selected in a way that only one component was the dominant substrate $[4,5,7,8]$. In those cases, a single substrate growth model is utilized to determine the biokinetic parameters. Phillips et al. [5] grew C. ljungdahlii in batch cultures with $\mathrm{H}_{2} / \mathrm{CO}_{2}$ or $\mathrm{CO} / \mathrm{CO}_{2}$ as the growth substrates to assess the influence of substrate on fermentation parameters used in process design. They concluded that $\mathrm{CO}$ provided a higher specific growth rate $\left(\mu=0.06 \mathrm{~h}^{-1}\right)$, whereas $\mathrm{H}_{2}$ brought about a higher specific uptake rate $\left(q=0.079 \mathrm{~mol} / \mathrm{g}_{\text {cell }} / \mathrm{h}\right)$. Vega et al. [9] obtained the fermentation parameters of Peptostreptococcus productus on gaseous substrates $\left(\mathrm{CO}, \mathrm{H}_{2} / \mathrm{CO}_{2}\right)$. Based on the achieved results it was deduced that only $\mathrm{CO}$ was consumed for the growth, whereas $\mathrm{CO}$ and $\mathrm{CO}_{2} / \mathrm{H}_{2}$ were utilized for production of acetate. They used some kinetic models including substrate inhibition to determine the biokinetic parameters; the results were $\mu_{\max }=0.21 \mathrm{~h}^{-1}$ and $q_{\max }=144 \mathrm{mmol} / \mathrm{g}_{\text {cell }} / \mathrm{h}$ with CO inhibitory effects on cell growth $\left(P_{\mathrm{CO}}^{L}>60 \mathrm{kPa}\right)$ and gas uptake $\left(P_{\mathrm{CO}}^{L}>80 \mathrm{kPa}\right)$.

In this work, the composition of synthesis gas was defined so that the partial pressures of $\mathrm{CO}, \mathrm{H}_{2}$, and $\mathrm{CO}_{2}$ were the same, which simulates the composition of synthesis gas obtained from the air-catalytic gasification [10]. In this case, the microbial growth is affected by more than a single substrate. In order to take into account such possibility, a dual-substrate growth model was used for C. ljungdahlii and the growth kinetic parameters were determined. Substrate inhibition effects in relation to the dissolved $\mathrm{CO}$ tension were discussed. Substrate uptake rate, mass transfer kinetics, and kinetics of product formation were also aspects of the discussion.

\section{Materials and Methods}

2.1. Microorganism and Growth Medium. Clostridium ljungdahlii (ATCC 55383) was grown anaerobically in a medium containing mineral salts, vitamins, and trace metals from ATCC 1754 PETC. The basal medium contained (per 1.0 L) mineral salts $\left(\mathrm{NH}_{4} \mathrm{Cl}(1.0 \mathrm{~g}), \mathrm{KCl}(0.1 \mathrm{~g}), \mathrm{MgSO}_{4} \cdot 7 \mathrm{H}_{2} \mathrm{O}\right.$
(0.2 g), $\mathrm{NaCl}(0.8 \mathrm{~g}), \mathrm{KH}_{2} \mathrm{PO}_{4}(0.1 \mathrm{~g})$, and $\mathrm{CaCl}_{2} \cdot 2 \mathrm{H}_{2} \mathrm{O}$ $(20.0 \mathrm{mg})), 1.0 \mathrm{~g}$ yeast extract, $10 \mathrm{~mL}$ trace elements solution, $10 \mathrm{~mL}$ vitamins solution, and $10 \mathrm{~mL}$ reducing agent. The trace elements solution contained (per $1.0 \mathrm{~L}$ ) nitrilotriacetic acid $(2.0 \mathrm{~g}), \mathrm{MnSO}_{4} \cdot \mathrm{H}_{2} \mathrm{O}(1.0 \mathrm{~g}), \mathrm{Fe}\left(\mathrm{SO}_{4}\right)_{2}\left(\mathrm{NH}_{4}\right)_{2} \cdot 6 \mathrm{H}_{2} \mathrm{O}(0.8 \mathrm{~g})$, $\mathrm{CoCl}_{2} \cdot 6 \mathrm{H}_{2} \mathrm{O}(0.2 \mathrm{~g}), \mathrm{ZnSO}_{4} \cdot 7 \mathrm{H}_{2} \mathrm{O}(0.2 \mathrm{mg}), \mathrm{CuCl}_{2} \cdot 2 \mathrm{H}_{2} \mathrm{O}$ (20.0 mg), $\mathrm{NiCl}_{2} \cdot 6 \mathrm{H}_{2} \mathrm{O}(20.0 \mathrm{mg}), \mathrm{Na}_{2} \mathrm{MoO}_{4} \cdot 2 \mathrm{H}_{2} \mathrm{O}(20.0 \mathrm{mg})$, $\mathrm{Na}_{2} \mathrm{SeO}_{4}(20.0 \mathrm{mg})$, and $\mathrm{Na}_{2} \mathrm{WO}_{4}(20.0 \mathrm{mg})$. The vitamins solution contained (per $1.0 \mathrm{~L}$ ) biotin $(2.0 \mathrm{mg})$, folic acid $(2.0 \mathrm{mg})$, pyridoxine hydrochloride $(10.0 \mathrm{mg})$, thiamine- $\mathrm{HCl}$ $(5.0 \mathrm{mg})$, riboflavin $(5.0 \mathrm{mg})$, nicotinic acid $(5.0 \mathrm{mg})$, calcium D-(+)-pantothenate $(5.0 \mathrm{mg})$, vitamin B12 (0.1 mg), p-aminobenzoic acid (5.0 mg), and thioctic acid $(5.0 \mathrm{mg})$. The reducing agent solution contained (per $100 \mathrm{~mL}$ ) $\mathrm{NaOH}$ (0.9 g), L-Cysteine- $\mathrm{HCl}$ (4.0 g), and $\mathrm{Na}_{2} \mathrm{~S} \cdot 9 \mathrm{H}_{2} \mathrm{O}(4.0 \mathrm{~g})$.

2.2. Batch Fermentation Experiments. The medium (excluding the reducing agent) was prepared, boiled, and dispensed anaerobically under nitrogen atmosphere into several Wheaton serum bottles (Borosilicate glass, Fischer Scientific, UK). Each serum bottle $(163 \mathrm{~mL})$ was filled with $50 \mathrm{~mL}$ of liquid medium. The reducing agent solution was prepared in separate serum bottle. All bottles were autoclaved at $121^{\circ} \mathrm{C}$ for $20 \mathrm{~min}$. The cool sterilized medium in each serum bottle was reduced by the addition of $1.6 \mathrm{~mL}$ reducing agent (per $50 \mathrm{~mL}$ medium). The $\mathrm{pH}$ of the media was adjusted to 5.9 using $1 \mathrm{M}$ $\mathrm{HCl}$ or $\mathrm{NaOH}$; then the synthesis gas containing $\mathrm{CO}, \mathrm{CO}_{2}$, $\mathrm{H}_{2}$, and $\mathrm{Ar}(30,30,30$, and $10 \%$, resp.) was purged into the bottles. Argon was used as internal standard to determine the total pressure changes inside the bottles and this inert gas did not interfere with the ability of the bacterium to produce ethanol and acetate. The bottles were then flushed with the substrate gas and pressurized to various initial pressures of $0.2,0.5,0.8,1.0,1.2$, and 1.5 atm (gauge). The media were inoculated $(10 \% \mathrm{v} / \mathrm{v})$ with seed culture harvested from a fermenter (Infors, Switzerland), operating with a continuous flow of synthesis gas (the same composition as the substrate gas in bottles) and medium defined. The bottles were then placed horizontally in an incubator shaker at $37^{\circ} \mathrm{C}$ and $150 \mathrm{rpm}$. For determination of the gas composition, optical density and ethanol and acetate concentrations samples were taken periodically at appropriate intervals.

2.3. Cell Density and Product Analysis. Optical density of the samples was analyzed using a spectrophotometer (Thermo Spectronic, USA) at $580 \mathrm{~nm}$ and the cell dry weight was determined using a predeveloped calibration curve. In order to calculate the substrate gas consumption, the gas phase was analyzed using a gas chromatograph (Perkin Elmer, Autosystem XL), equipped with a thermal conductivity detector (TCD) and a packed column, $15 \mathrm{ft} \times 1 / 8$ in., 100/120 mesh, Carboxene 1000 (Supelco). Detection of ethanol and acetate was performed using another gas chromatograph (Agilent, 5890 series II), equipped with a flame ionization detector (FID). The chromatography column was $80 / 120$ mesh Carbopack B-DA/4\% Carbowax 20 M (Supelco, USA). The samples were previously acidified and 2-pentanone was used as internal standard. 
TABLE 1: Kinetic parameters based on Volterra model for growth of C. ljungdahlii.

\begin{tabular}{lccccc}
\hline $\begin{array}{l}\text { Initial gas pressure } \\
\text { atm }\end{array}$ & $\begin{array}{c}x_{0} \\
\mathrm{mg} / \mathrm{L}\end{array}$ & $\begin{array}{c}x_{m} \\
\mathrm{mg} / \mathrm{L}\end{array}$ & $\begin{array}{c}\mu_{m} \\
\mathrm{~h}^{-1}\end{array}$ & $\begin{array}{c}k \\
\mathrm{~h}^{-1}\end{array}$ & $R^{2}$ \\
\hline 0.2 & 47.07 & 70.79 & 0.153 & 0.008 & 0.972 \\
0.5 & 43.92 & 97.51 & 0.155 & 0.031 & 0.947 \\
0.8 & 42.80 & 98.94 & 0.185 & 0.025 & 0.969 \\
1.0 & 44.48 & 150.89 & 0.196 & 0.033 & 0.987 \\
1.2 & 44.76 & 135.63 & 0.145 & 0.042 & 0.991 \\
1.5 & 41.87 & 101.00 & 0.138 & 0.034 & 0.948 \\
\hline
\end{tabular}

\section{Results and Discussion}

3.1. Kinetics of Microbial Growth. In batch cultivation of $C$. ljungdahlii, the cells started the exponential growth without going through any lag phase. This was because of the use of metabolically active inocula, preadapted to the synthesis gas, which were harvested from an actively operating bioreactor. Almost all cultures, with various initial gas pressures, reached a maximum growth after which the culture density decreased. To describe the growth profile of C. ljungdahlii on synthesis gas at various initial pressures, Volterra kinetic model was used. This model is able to predict both the birth and death phases of growth and considers them the only factors which change the cell population in a batch system $[7,11]$ :

$$
x=\frac{x_{0} \exp \left(\mu_{m} t\right)}{1-\left(x_{0} / x_{m}\right)^{2}\left(\mu_{m} /\left(k+\mu_{m}\right)\right)\left(1-\exp \left(\left(k+\mu_{m}\right) \cdot t\right)\right)},
$$

where $x_{0}$ is the initial cell concentration $(\mathrm{g} / \mathrm{L}), x_{m}$ expresses the maximum cell density $(\mathrm{g} / \mathrm{L}), \mu_{m}$ is the maximum specific growth rate $\left(\mathrm{h}^{-1}\right), t$ represents the fermentation period $(\mathrm{h})$, and $k$ is the cell decline or promotion constant $\left(\mathrm{h}^{-1}\right)$.

Figure 1 shows the Volterra model applied to the experimental data. The model fitted to the experimental results with high regression coefficients $\left(R^{2}\right)$ at all specified pressures. The kinetic parameters of this model are summarized in Table 1.

The constant $k$ is associated with the inhibition or promotion of the cell growth. A negative value of $k$ implies that the cell growth is promoted, whereas a positive value is an indication of inhibition caused by toxic chemicals. A positive value of $k$ was achieved in all cases indicating that the bacterial cell growth declined after reaching a maximum cell concentration due to some inhibitory effects caused by CO. Generally, in biological processes, reactant products or contaminants can impose inhibitory effect on cell growth and/or product formation. In the case of synthesis gas fermentation, $\mathrm{CO}$ could be the most probable potential source of inhibition. $\mathrm{CO}_{2}$ can also be another potential source of inhibition, as it affects the medium $\mathrm{pH}$ by the formation of carbonic acid or its carbonate derivatives [12]. However, in this experiment, no appreciable $\mathrm{pH}$ drop occurred in the cultures, implying that $\mathrm{CO}_{2}$ did not cause inhibition. Increase of $\mathrm{H}_{2}$ partial pressure in the gas phase or its accumulation in the fermentation medium can also impose inhibition on the fermentation process due to the alteration of carbon flow in

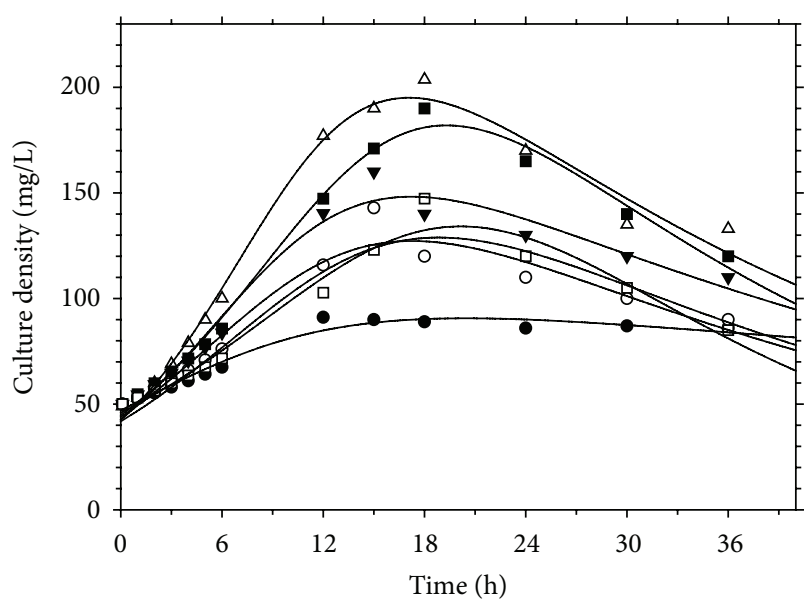

Figure 1: The Volterra model applied to the experimental data at various synthesis gas pressures; 0 : $0.2, \bigcirc: 0.5, \boldsymbol{\nabla}: 0.8, \Delta: 1.0, \mathbf{\square}: 1.2, \square$ : 1.5 (atm), and -: (5).

the biological pathway of microorganism [13]. Nevertheless, the solubility of $\mathrm{H}_{2}$ in liquid medium is much less than that of CO [14]; thus, it was speculated that CO was the primary source of inhibition in the current experiment.

As observed in Figure 1, the cell population declined, after reaching a maximum, without experiencing any stationary phase. It could be deduced that the cell population in the batch bioreactors was not enough to consume all the $\mathrm{CO}$ transferred to the liquid phase. This probably resulted in the buildup of liquid phase concentration of $\mathrm{CO}$ which eventually inhibited the cell growth and caused the cell death. Such inhibitory effect was more severe at high synthesis gas pressures. Although the higher concentration gradients increased the mass transfer rate, this promoted rate was somewhat higher than the rate of CO uptake which caused inhibition on growth rate.

According to Bailey and Ollis [15], when microbial cell growth is limited by more than one substrate, three forms of multiple-substrate growth models need to be considered to describe the growth.

Interactive or multipleactive form is

$$
\frac{\mu}{\mu_{\max }}=\left[\mu\left(S_{1}\right)\right]\left[\mu\left(S_{2}\right)\right] \cdots\left[\mu\left(S_{i}\right)\right] .
$$

Additive form is

$$
\frac{\mu}{\mu_{\max }}=\frac{\left[\mu\left(S_{1}\right)+\mu\left(S_{2}\right)+\cdots+\mu\left(S_{i}\right)\right]}{i} .
$$

Noninteractive form is

$$
\frac{\mu}{\mu_{\max }}=\mu\left(S_{1}\right) \text { or } \mu\left(S_{2}\right) \text { or } \cdots \text { or } \mu\left(S_{i}\right) \text {. }
$$

It was hypothesized that C. ljungdahlii was able to grow on either of the limiting substrates, hydrogen or carbon monoxide, based on reactions (1)-(4), and the microbial growth was not hindered in the absence of any of them. To prove this, a plot of cell concentration versus the consumption 
TABLE 2: Various single substrate kinetic models used to develop a dual-substrate growth model.

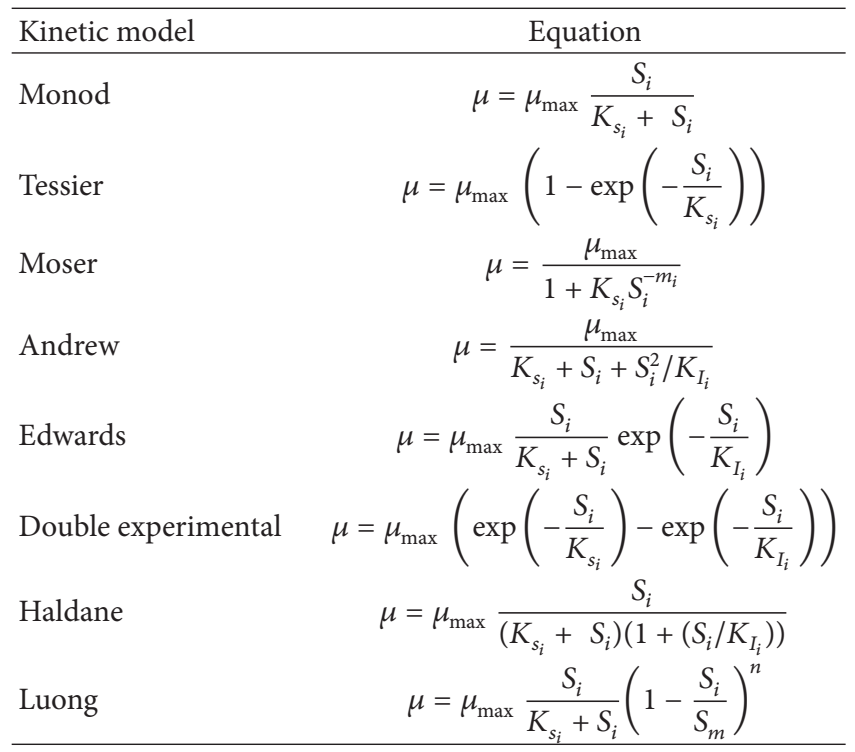

of both substrates $\left(\mathrm{CO}\right.$ and $\mathrm{H}_{2}$ ) was developed and a linear relationship was found indicating that both substrates were consumed for cell growth (data not shown) [9]. This implies that the growth kinetic followed the additive form (7), and (6) and (8) were not applicable in this case.

In order to describe the microbial growth rate $(\mu)$ as a function of dual-substrate $\left(\mathrm{CO}, \mathrm{H}_{2}\right)$ concentrations, various single substrate growth models (Table 2), including substrate inhibition models, were combined as described by (7).

Various combinations of several kinetic models (presented in Table 3) in additive form were used to develop the biokinetic expressions able to describe the growth behavior of C. liungdahlii. The sum of squares of differences (SSD) between the experimentally measured specific growth rates and the calculated ones by the mathematical models was used as a predefined objective function:

$$
\mathrm{SSD}=\sum_{i=1}^{N}\left(\mu_{\exp }-\mu_{\text {model }}\right)^{2}
$$

Minimizing this objective function was required to calculate the biokinetic parameters from the experimental data [16]. To improve the accuracy of the double parametric model, random data sets, similar to the experimental data, within the range of dissolved $\mathrm{CO}$ and $\mathrm{H}_{2}$ tensions and calculated specific growth rates, were generated using standard Excel RAND function. The generated data were used to evaluate the suitability of the developed kinetic models to predict the dual-substrate growth rate of C. ljungdahlii. Sigma Plot 11 was used to develop the combined kinetic models and to calculate the biokinetic parameters. Models that resulted in negative values extremely high or out of range biokinetic constants were rejected. The best dual-substrate growth model was selected among the different additive combinations of the models presented in Table 2.

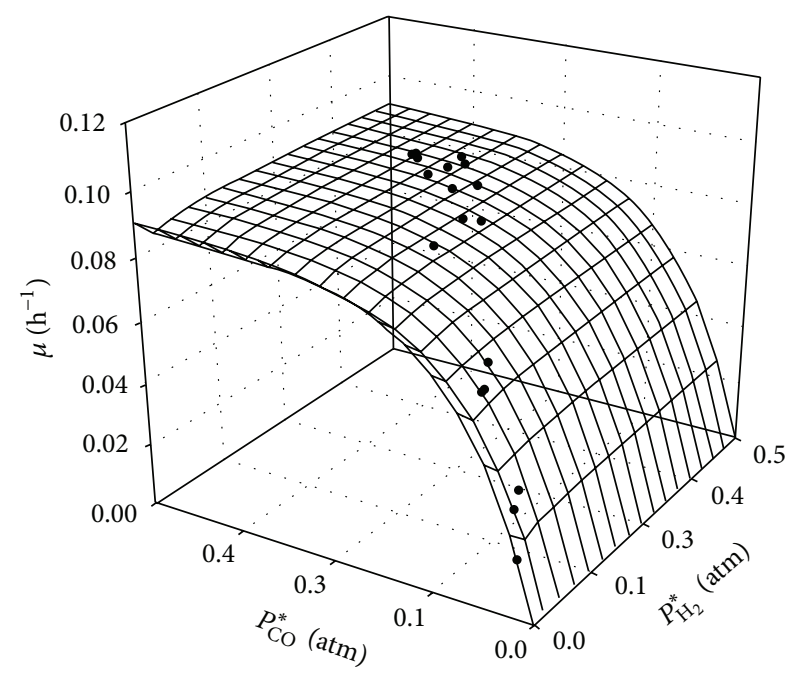

FIGURE 2: The specific growth rate predicted from (10) applied to the experimental data.

The calculated biokinetic parameters and SSD values for each combined model are tabulated in Table 3 . The minimum SSD was found for an additive combination of Luong and Monod kinetics. This model was selected as the best kinetic model to describe the growth of C. ljungdahlii on $\mathrm{CO}$ and $\mathrm{H}_{2}$ :

$$
\mu=\frac{\mu_{\max }}{2\left(\left(S_{\mathrm{CO}} /\left(K_{s, \mathrm{CO}}+S_{\mathrm{CO}}\right)\right)\left(1-S_{\mathrm{CO}} / S_{m}\right)^{n}+S_{\mathrm{H}_{2}} /\left(K_{s, \mathrm{H}_{2}}+S_{\mathrm{H}_{2}}\right)\right)},
$$

where $\mu_{\max }$ is the maximum specific growth rate $\left(\mathrm{h}^{-1}\right), K_{s, \mathrm{CO}}$ and $K_{s, \mathrm{H}_{2}}$ are the Monod constant for $\mathrm{CO}$ and $\mathrm{H}_{2}$ (atm), $S_{m, \mathrm{CO}}$ represents the maximum inhibitory concentration of $\mathrm{CO}$ at which no growth is apparent, and $n$ is the constant for Luong model which accounts for the relationship between $\mu$ and $S$ [17]. For the selected model, the biokinetic parameters were obtained as $\mu_{\max }=0.195 \mathrm{~h}^{-1}, K_{s, \mathrm{CO}}=0.855 \mathrm{~atm}, K_{s, \mathrm{H}_{2}}=$ $0.412 \mathrm{~atm}, S_{m, \mathrm{CO}}=0.743 \mathrm{~atm}$, and $n=0.465$. Figure 2 shows the specific growth rate as a function of the $\mathrm{CO}$ and $\mathrm{H}_{2}$ dissolved tensions; the experimental data were fitted to (10).

3.2. Kinetics of Substrate Gas Utilization. The anaerobic bacterium C. ljungdahlii is able to utilize CO through the WoodLjungdahl pathway, to produce acetate and ethanol based on (1) and (3). An alternative route involves the conversion of $\mathrm{CO}_{2}$ and $\mathrm{H}_{2}$ to ethanol and acetate through the same set of enzymes and transformation mechanism encompassed by the acetyl-CoA pathway according to (2) and (4). In the current study, $\mathrm{H}_{2}$ consumption was higher than $\mathrm{CO}$ at all gas pressures. Such observation signifies that the bacteria consumed $\mathrm{H}_{2} / \mathrm{CO}_{2}$ as the preferred substrate through the homoacetic pathway. The highest substrate conversion efficiency of $76 \%$ for $\mathrm{H}_{2}$ and $67 \%$ for $\mathrm{CO}$ was achieved at the initial synthesis gas pressure of $1.0 \mathrm{~atm}$.

To describe the substrate gas utilization by the bacterium, a first order reaction kinetic was used. The expression for $\mathrm{CO}$ 
TABLE 3: The developed dual-substrate growth models to describe the growth kinetics of C. ljungdahlii on $\mathrm{H}_{2}$ and CO, biokinetic parameters, and SSD.

\begin{tabular}{|c|c|c|c|c|c|c|c|}
\hline Model $^{*}$ & $\begin{array}{c}\mu_{\max } \\
\mathrm{h}^{-1}\end{array}$ & $\begin{array}{c}K_{s, \mathrm{CO}} \\
\mathrm{atm}\end{array}$ & $\begin{array}{c}K_{\mathrm{S}, \mathrm{H}_{2}} \\
\text { atm }\end{array}$ & $\begin{array}{c}K_{I, \mathrm{CO}} \\
\text { atm }\end{array}$ & $\begin{array}{c}S_{m, \mathrm{CO}} \\
\mathrm{atm}\end{array}$ & $\begin{array}{l}n \\
-\end{array}$ & SSD \\
\hline Luong + Monod & 0.1951 & 0.8551 & 0.4124 & - & 0.7432 & 0.4652 & 0.0005 \\
\hline Double-experimental + Monod & 0.1763 & 0.3051 & 0.3006 & 0.3741 & - & - & 0.0010 \\
\hline Luong + Tessier & 0.1600 & 0.8524 & 0.4120 & - & 0.7431 & 0.4736 & 0.0010 \\
\hline Double-experimental + Moser & 0.1764 & 0.3051 & 0.3008 & 0.3740 & - & - & 0.0010 \\
\hline Luong + Moser & 0.1009 & 0.3070 & 0.3001 & - & 0.7470 & 0.1249 & 0.0011 \\
\hline Double-experimental + Tessier & 0.1473 & 0.6353 & 0.3990 & 0.4713 & - & - & 0.0013 \\
\hline Andrew + Tessier & 0.1555 & 1.038 & 0.3290 & 0.4001 & - & - & 0.0014 \\
\hline Edwards + Monod & 0.1755 & 0.6396 & 0.3912 & 0.6998 & - & - & 0.0014 \\
\hline Edwards + Tessier & 0.1585 & 0.8110 & 0.399 & 0.6243 & - & - & 0.0014 \\
\hline Andrew + Monod & 0.1650 & 0.6995 & 0.3778 & 0.4876 & - & - & 0.0015 \\
\hline Haldane + Moser & 0.1580 & 0.5393 & 0.4050 & 0.7315 & - & - & 0.0015 \\
\hline Haldane + Monod & 0.1549 & 0.5573 & 0.3749 & 0.7128 & - & - & 0.0016 \\
\hline
\end{tabular}

${ }^{*}$ In each combination, the first model is used for $\mathrm{CO}$ and the second one for $\mathrm{H}_{2}$.

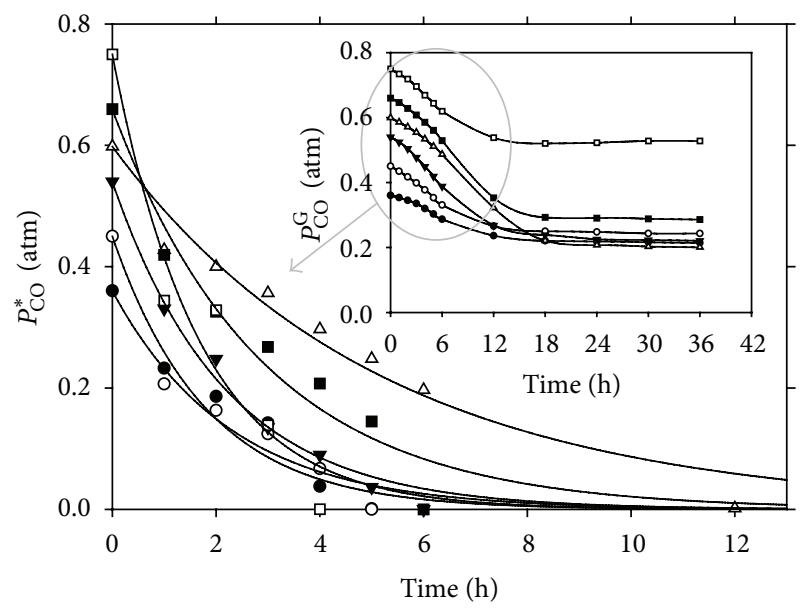

FIGURE 3: Measured CO partial pressure in the gas phase (the inset) and calculated dissolved $\mathrm{CO}$ tension in liquid in various pressurized batch bioreactors; $\bullet: 0.2, \bigcirc: 0.5, \mathbf{\nabla}: 0.8, \Delta: 1.0, \mathbf{\square}: 1.2$, and $\square: 1.5$ (atm).

consumption with respect to the fermentation time in the form of first order differential equation is as follows:

$$
-\frac{d P_{\mathrm{CO}}^{*}}{d t}=k_{p} P_{\mathrm{CO}}^{*}
$$

The expression for time dependent CO liquid phase concentration is obtained by integrating from the first order consumption rate which leads to:

$$
P_{\mathrm{CO}}^{*}=P_{\mathrm{CO}, 0}^{*} \exp \left(k_{p} t\right),
$$

where $P_{\mathrm{CO}, 0}^{*}$ and $P_{\mathrm{CO}}^{*}$ are the initial and instantaneous dissolved CO tensions in the liquid phase (atm), $k_{p}$ is the first order rate constant $\left(\mathrm{h}^{-1}\right)$, and $t$ is the fermentation time (h).

Figure 3 describes the dissolved CO reduction in batch culture for various pressurized bioreactors. As observed, the first order reaction model was suitable to describe the kinetics of the $\mathrm{CO}$ utilization with high regression coefficient $\left(R^{2}>0.94\right)$ for all pressures. However, study of the effect of initial gas pressure on substrate gas uptake showed the potential inhibitory effect of $\mathrm{CO}$ on the cell growth and substrate gas uptake at pressures above $1.0 \mathrm{~atm}$. Increase of the initial gas pressure from 0.2 to $1.0 \mathrm{~atm}$ improved the substrate gas utilization due to the enhanced mass transfer rates. However, increase of the gas pressure to beyond 1.0 atm adversely affected the substrate gas uptake and cell growth. At high pressures, the dissolved CO concentration reached toxic levels, as the cell concentration was insufficient to keep the reaction in mass transfer limited regime. The increase of the reactor pressure (above $1.0 \mathrm{~atm}$ ) improved the mass transfer rate above the intrinsic biological reaction rate. As a result, buildup of the liquid phase concentration of $\mathrm{CO}$ imposed an inhibitory effect on the microbial growth and gas uptake. These results suggest the employment of pressurized operation as long as the cell concentration is high enough to keep the dissolved CO tensions at low levels to prevent any possibility of CO inhibition.

3.3. Kinetics of Substrate Gas Uptake Rate and Mass Transfer. The data obtained at various gas pressures were used to determine the kinetics of $\mathrm{CO}$ uptake rate using a modified Monod model proposed by Andrews which accommodates CO inhibition [18]:

$$
q_{\mathrm{CO}}=\frac{q_{\mathrm{max}} P_{\mathrm{CO}}^{*}}{K_{p}+P_{\mathrm{CO}}^{*}+P_{\mathrm{CO}}^{*} / K_{I}},
$$

where $P_{\mathrm{CO}}^{*}$ is the dissolved $\mathrm{CO}$ tension in the liquid phase (atm), $q_{\max }$ represents the maximum specific uptake rate $\left(\mathrm{mmol} / \mathrm{g}_{\text {cell }} / \mathrm{h}\right), K_{p}$ is the Monod constant $(\mathrm{atm})$, and $K_{I}$ is the CO inhibition constant (atm).

Determination of the kinetic parameters in (13) is not straightforward due to the difficulties involved in measuring the liquid phase concentration of $\mathrm{CO}$. The procedure to find 


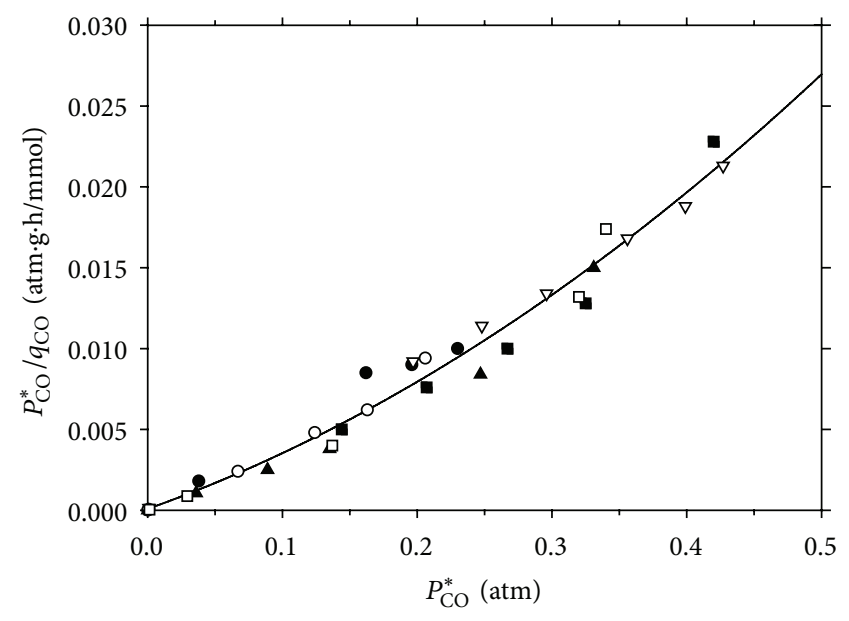

Figure 4: Linear and quadratic Andrews model for CO uptake by C. ljungdahlii at various gas pressures; $0.2,0: 0.5, \mathbf{\nabla}: 0.8, \Delta: 1.0$, $\mathbf{\square}$ : 1.2 , and $\square: 1.5$ (atm).

the dissolved CO tension involves the determination of the mass transfer coefficient $\left(K_{\mathrm{L}} a\right)$ using a mass balance on the rate of transfer of $\mathrm{CO}$ to the liquid medium:

$$
-\frac{1}{V_{\mathrm{L}}} \frac{d n_{\mathrm{CO}}^{\mathrm{G}}}{d t}=\frac{K_{\mathrm{L}} a}{H}\left(P_{\mathrm{CO}}^{\mathrm{G}}-P_{\mathrm{CO}}^{*}\right)
$$

where $V_{\mathrm{L}}$ is the medium volume $(\mathrm{L}), n_{\mathrm{CO}}^{\mathrm{G}}$ represents the moles of CO in the gas phase (mmol), $t$ is the fermentation time (h), $K_{\mathrm{L}} a$ corresponds to the mass transfer coefficient $\left(\mathrm{h}^{-1}\right), H$ is the Henry's constant $(\mathrm{atm} \cdot \mathrm{L} / \mathrm{mmol})$, and $P_{\mathrm{CO}}^{\mathrm{G}}$ and $P_{\mathrm{CO}}^{*}$ represent the gas phase and dissolved $\mathrm{CO}$ tension in the liquid phase (atm), respectively. Under the mass transfer controlled condition, where the $P_{\mathrm{CO}}^{*}$ is assumed to be zero, $K_{\mathrm{L}} a$ is obtained from the following equation:

$$
-\frac{1}{V_{\mathrm{L}}} \frac{d n_{\mathrm{CO}}^{\mathrm{G}}}{d t}=\frac{K_{\mathrm{L}} a}{H} P_{\mathrm{CO}}^{\mathrm{G}}
$$

The value of $P_{\mathrm{CO}}^{*}$ is calculated at the early stage of the fermentation process, where the mass transfer is not the controlling mechanism.

The rate of disappearance of $\mathrm{CO}$ in the liquid phase as a result of microbial uptake is obtained by the following equation:

$$
q_{\mathrm{CO}}=\frac{1}{x V_{\mathrm{L}}} \frac{d n_{\mathrm{CO}}}{d t},
$$

where $q_{\mathrm{CO}}$ represents the specific uptake rate $\left(\mathrm{mmol} / \mathrm{g}_{\text {cell }} / \mathrm{h}\right)$ and $x$ is the cell density $(\mathrm{g} / \mathrm{L})$. By rearranging (13) to form (17), the kinetic parameters are found by a linear and quadratic regression:

$$
\frac{P_{\mathrm{CO}}^{*}}{q_{\mathrm{CO}}}=\frac{K_{P}}{q_{\max }}+\frac{P_{\mathrm{CO}}^{*}}{q_{\max }}+\frac{P_{\mathrm{CO}}^{*}{ }^{2}}{q_{\max } K_{I}} .
$$

Figure 4 shows the specific CO uptake rate for various initial gas pressures. As observed, all data were represented
TABLE 4: Calculated biokinetic parameters using the modified Gompertz model for product formation.

\begin{tabular}{cccccc}
\hline Product & $\begin{array}{c}\text { Pressure } \\
\text { atm }\end{array}$ & $\begin{array}{c}P_{\max } \\
\mathrm{mmol} / \mathrm{L}\end{array}$ & $\begin{array}{c}R_{\max } \\
\mathrm{mmol} / \mathrm{L} / \mathrm{h}\end{array}$ & $\begin{array}{c}\lambda \\
\mathrm{h}\end{array}$ & $R^{2}$ \\
\hline \multirow{6}{*}{ Ethanol } & 0.2 & 1.5742 & 0.0223 & 6.0333 & 0.9125 \\
& 0.5 & 2.2386 & 0.0394 & 7.3126 & 0.9193 \\
& 0.8 & 3.1463 & 0.0808 & 9.1129 & 0.8989 \\
& 1.0 & 4.7592 & 0.1722 & 7.7737 & 0.9624 \\
& 1.2 & 2.5861 & 0.0672 & 8.6630 & 0.9073 \\
Acetate & 1.5 & 1.9433 & 0.0464 & 8.7915 & 0.9153 \\
\hline \multirow{6}{*}{} & 0.2 & 5.0161 & 0.0542 & 3.1672 & 0.9509 \\
& 0.5 & 5.1703 & 0.0706 & 2.5373 & 0.9050 \\
& 1.0 & 6.9560 & 0.0963 & 2.3957 & 0.9053 \\
& 1.2 & 5.2264 & 0.0877 & 4.6254 & 0.9037 \\
& 1.5 & 5.5812 & 0.0711 & 2.1636 & 0.8928 \\
\hline
\end{tabular}

by a single quadratic curve with a high regression coefficient $\left(R^{2}=0.97\right)$. The final expression correlating the specific $\mathrm{CO}$ uptake rate of $C$. ljungdahlii is described by the following equation:

$$
q_{\mathrm{CO}}=\frac{34.36 P_{\mathrm{CO}}^{*}}{0.021+P_{\mathrm{CO}}^{*}+P_{\mathrm{CO}}^{*} / 0.601} .
$$

The maximum specific $\mathrm{CO}$ uptake rate, $q_{\max }$, was obtained as $34.364 \mathrm{mmol} / \mathrm{g}_{\text {cell }} / \mathrm{h}$ and the Monod constant, $K_{p}$, was $0.021 \mathrm{~atm}$. The $\mathrm{CO}$ inhibition constant, $K_{I}$, had a value of $0.601 \mathrm{~atm}$ indicating that the dissolved CO significantly inhibits CO uptake.

3.4. Kinetics of Product Formation. C. ljungdahlii as an ethanologenic acetogen presents a complex metabolic pathway which includes both acetogenic and solventogenic phases [19]. Although ethanol is the desirable product from the solventogenic fermentation of synthesis gas, acetate is the main product formed through the acetogenic pathway. The formation kinetics of ethanol or acetate as the fermentation products was studied using a modified Gompertz equation which is defined as [20]

$$
P=P_{\max } \exp \left(-\exp \left[\frac{R_{\max } \times e}{P_{\max }}(\lambda-t)+1\right]\right),
$$

where $P$ represents the amount of product (ethanol or acetate) formed $(\mathrm{mmol} / \mathrm{L}), P_{\max }$ is the maximum product formed $(\mathrm{mmol} / \mathrm{L}), R_{\max }$ is the maximum rate of production $(\mathrm{mmol} / \mathrm{L} / \mathrm{h}), \lambda$ is the lag time to exponential product formation (h), and $t$ is the fermentation time (h).

The fitted curves for ethanol and acetate are depicted in Figures 5(a) and 5(b) and the kinetic parameters for various pressurized bioreactors are tabulated in Table 4 . The correlation coefficients were almost above 0.90 in all cases suggesting the suitability of the modified Gompertz model to describe the formation of ethanol and acetate by $C$. ljungdahlii during the batch fermentation of synthesis gas. 


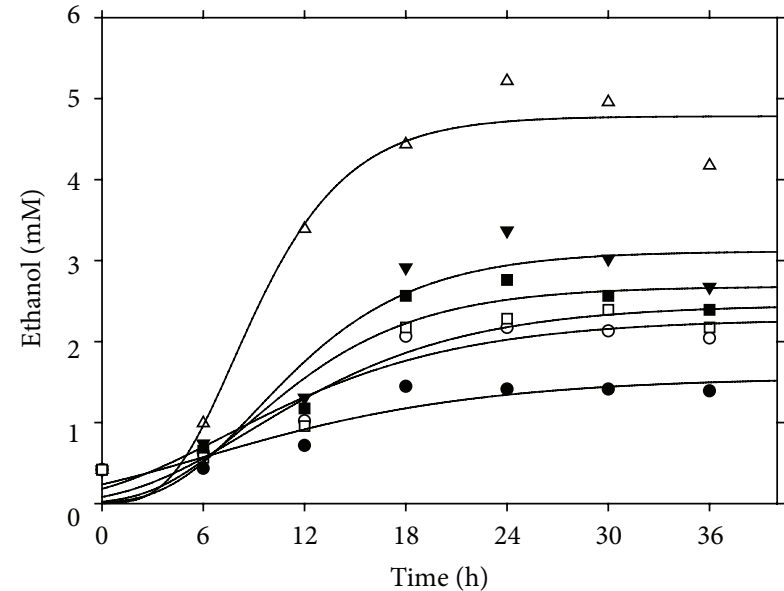

(a)

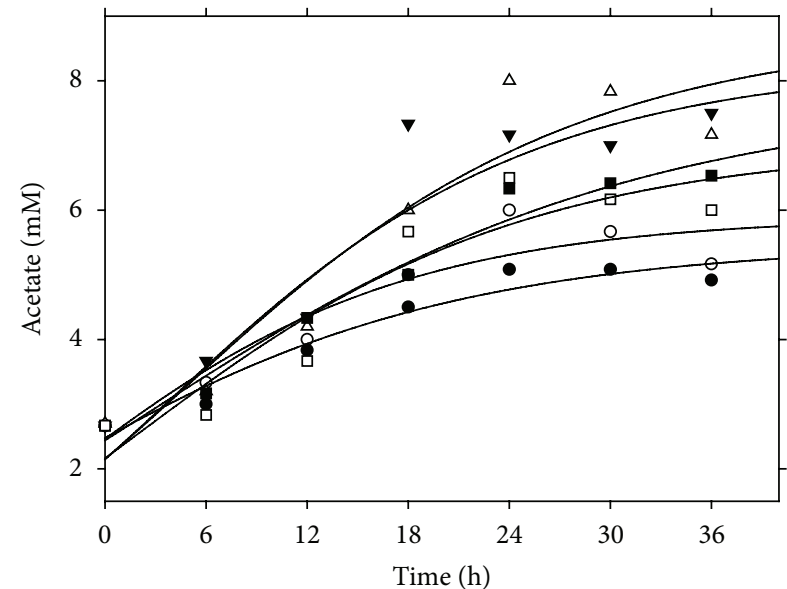

(b)

FIGURE 5: Modified Gompertz model for the formation of (a) ethanol and (b) acetate at various gas pressures; $\bullet: 0.2, \bigcirc: 0.5, \boldsymbol{\nabla}: 0.8, \Delta: 1.0$, 1.2 , and $\square: 1.5$ (atm).

\section{Conclusion}

Fermentation parameters of C. ljungdahlii grown on synthesis gas at various initial gas pressures were obtained using several unstructured kinetic models. A dual-substrate growth model which combined Luong (for $\mathrm{CO}$ ) and Monod (for $\mathrm{H}_{2}$ ) kinetics was used to describe the growth rate of the bacterium on $\mathrm{CO}$ and $\mathrm{H}_{2}$. Volterra kinetic model and Andrews which both include possible inhibitions were applied to describe the cell growth and CO uptake rate. The kinetic models confirmed possible CO inhibition on cell growth and gas uptake at high dissolved CO tensions which were experimentally observed in pressurized batch bioreactors. The modified Gompertz equation employed to model the product formation was also suitable to describe the ethanol and acetate formation.

\section{Nomenclature}

$H: \quad$ Henry's constant $(\mathrm{atm} \cdot \mathrm{L} / \mathrm{mmol})$

$k$ : $\quad$ Cell decline or promotion constant $\left(\mathrm{h}^{-1}\right)$

$K_{I, \mathrm{CO}}$ : Inhibition constant for $\mathrm{CO}$ (atm)

$K_{\mathrm{L}} a: \quad$ Mass transfer coefficient $\left(\mathrm{h}^{-1}\right)$

$k_{p}$ : $\quad$ First order rate constant $\left(\mathrm{h}^{-1}\right)$

$K_{s, \mathrm{CO}}$ : Monod half-saturation constant for $\mathrm{CO}$ (atm)

$K_{s, \mathrm{H}_{2}}$ : Monod half-saturation constant for $\mathrm{H}_{2}$ (atm)

$m: \quad$ Moser's constant for substrate $i(\mathrm{~g} / \mathrm{L})$

$n$ : Constant for Loung model

$n_{\mathrm{CO}}^{\mathrm{G}}$ : Moles of CO in the gas phase ( $\left.\mathrm{mmol}\right)$

$P_{\mathrm{CO}}^{*}$ : Instantaneous dissolved $\mathrm{CO}$ tension in the liquid phase (atm)

$P_{\mathrm{CO}, 0}^{*}$ : Initial dissolved $\mathrm{CO}$ tension in the liquid phase (atm)

$P_{\mathrm{CO}}^{\mathrm{G}}: \quad$ Gas phase pressure of $\mathrm{CO}(\mathrm{atm})$

$P: \quad$ Amount of product formed $(\mathrm{mmol} / \mathrm{L})$

$P_{\max }:$ Maximum product formed $(\mathrm{mmol} / \mathrm{L})$
$q_{\mathrm{CO}}: \quad$ Specific CO uptake rate $\left(\mathrm{mmol} / \mathrm{g}_{\text {cell }} / \mathrm{h}\right)$

$q_{\max }$ : Maximum specific uptake rate $\left(\mathrm{mmol} / \mathrm{g}_{\text {cell }} / \mathrm{h}\right)$

$R_{\text {max }}:$ Maximum rate of production $(\mathrm{mmol} / \mathrm{L} / \mathrm{h})$

$S_{i}$ : $\quad$ Pressure of substrate $i$ (atm)

$S_{m, \mathrm{CO}}$ : Maximum inhibitory pressure of $\mathrm{CO}$ at which no growth is apparent (atm)

SSD: Sum of squares of differences

$t: \quad$ Fermentation period (h)

$V_{\mathrm{L}}: \quad$ Volume of medium (L)

$x: \quad$ Instantaneous cell concentration $(\mathrm{g} / \mathrm{L})$

$x_{0}: \quad$ Initial cell concentration $(\mathrm{g} / \mathrm{L})$

$x_{m}$ : Maximum cell concentration $(\mathrm{g} / \mathrm{L})$.

Greek Symbols

$\mu: \quad$ Specific growth rate $\left(\mathrm{h}^{-1}\right)$

$\mu_{m}$ : Maximum specific growth rate $\left(\mathrm{h}^{-1}\right)$

$\mu_{\text {exp }}$ : Experimentally determined specific growth rate $\left(\mathrm{h}^{-1}\right)$

$\mu_{\text {model }}$ : Specific growth rate predicted from model $\left(\mathrm{h}^{-1}\right)$

$\lambda$ : $\quad$ Lag time to exponential product formation (h).

\section{Conflict of Interests}

The authors declare that there is no conflict of interests.

\section{Acknowledgments}

The authors gratefully acknowledge Universiti Sains Malaysia and the Ministry of Higher Education Malaysia for funding this project in the form of RU Team Grant (1001/ PJKIMIA/854001) and Long Term Research Grant Scheme (203/PKT/6723001). The authors also would like to acknowledge Iran National Science Foundation (INSF). 


\section{References}

[1] M. Mohammadi, G. D. Najafpour, H. Younesi, P. Lahijani, M. H. Uzir, and A. R. Mohamed, "Bioconversion of synthesis gas to second generation biofuels: a review," Renewable and Sustainable Energy Reviews, vol. 15, no. 9, pp. 4255-4273, 2011.

[2] M. Köpke, C. Mihalcea, J. C. Bromley, and S. D. Simpson, "Fermentative production of ethanol from carbon monoxide," Current Opinion in Biotechnology, vol. 22, no. 3, pp. 320-325, 2011.

[3] M. Köpke, C. Held, S. Hujer et al., "Clostridium ljungdahlii represents a microbial production platform based on syngas," Proceedings of the National Academy of Sciences of the United States of America, vol. 107, no. 29, pp. 13087-13092, 2010.

[4] J. L. Vega, S. Prieto, B. B. Elmore, E. C. Clausen, and J. L. Gaddy, "The biological production of ethanol from synthesis gas," Applied Biochemistry and Biotechnology, vol. 20-21, no. 1, pp. 781-797, 1989.

[5] J. R. Phillips, E. C. Clausen, and J. L. Gaddy, "Synthesis gas as substrate for the biological production of fuels and chemicals," Applied Biochemistry and Biotechnology, vol. 45-46, no. 1, pp. 145-157, 1994.

[6] I. S. Chang, B. H. Kim, R. W. Lovitt, and J. S. Bang, "Effect of CO partial pressure on cell-recycled continuous CO fermentation by Eubacterium limosum KIST612," Process Biochemistry, vol. 37, no. 4, pp. 411-421, 2001.

[7] H. Younesi, G. Najafpour, and A. R. Mohamed, "Ethanol and acetate production from synthesis gas via fermentation processes using anaerobic bacterium, Clostridium ljungdahlii," Biochemical Engineering Journal, vol. 27, no. 2, pp. 110-119, 2005.

[8] J. L. Gaddy and E. C. Clausen, "Clostridium ljungdahlii, an anaerobic ethanol and acetate producing microorganism," Us Patent 5, 173, 429, 1992.

[9] J. L. Vega, V. L. Holmberg, E. C. Clausen, and J. L. Gaddy, "Fermentation parameters of Peptostreptococcus productus on gaseous substrates $\left(\mathrm{CO}, \mathrm{H}_{2} / \mathrm{CO}_{2}\right)$," Archives of Microbiology, vol. 151, no. 1, pp. 65-70, 1988.

[10] D. R. McIlveen-Wright, F. Pinto, L. Armesto et al., "A comparison of circulating fluidised bed combustion and gasification power plant technologies for processing mixtures of coal, biomass and plastic waste," Fuel Processing Technology, vol. 87, no. 9, pp. 793-801, 2006.

[11] G. D. Najafpour, M. Tajallipour, M. Komeili, and M. Mohammadi, "Kinetic model for an up-flow anaerobic packed bed bioreactor: dairy wastewater treatment," African Journal of Biotechnology, vol. 8, no. 15, pp. 3590-3596, 2009.

[12] A. Amos, "Biological water-gas shift conversion of carbon monoxide to hydrogen," Milestone Completion Report, National Renewable Energy Laboratory (NREL) MP-56035592, 2004.

[13] Y. Q. Nie, H. Liu, G. C. Du, and J. Chen, "Acetate yield increased by gas circulation and fed-batch fermentation in a novel syntrophic acetogenesis and homoacetogenesis coupling system," Bioresource Technology, vol. 99, no. 8, pp. 2989-2995, 2008.

[14] M. D. Bredwell, P. Srivastava, and R. M. Worden, "Reactor design issues for synthesis-gas fermentations," Biotechnology Progress, vol. 15, no. 5, pp. 834-844, 1999.

[15] J. E. Bailey and D. F. Ollis, Biochemical Engineering Fundamentals, McGraw-Hill, New York, NY, USA, 2nd edition, 1986.
[16] N. Yurt, J. Sears, and Z. Lewandowski, "Multiple substrate growth kinetics of Leptothrix discophora SP6," Biotechnology Progress, vol. 18, no. 5, pp. 994-1002, 2002.

[17] J. H. T. Luong, "Generalization of monod kinetics for analysis of growth data with substrate inhibition," Biotechnology and Bioengineering, vol. 29, no. 2, pp. 242-248, 1987.

[18] G. Najafpour, H. Younesi, and A. R. Mohamed, "Effect of organic substrate on hydrogen production from synthesis gas using Rhodospirillum rubrum, in batch culture," Biochemical Engineering Journal, vol. 21, no. 2, pp. 123-130, 2004.

[19] M. Mohammadi, A. R. Mohamed, G. D. Najafpour, H. Younesi, and M. H. Uzir, "Effect of organic substrate on promoting solventogenesis in ethanologenic acetogene Clostridium ljungdahlii ATCC55383," International Journal of EngineeringTransactions B, vol. 27, no. 2, pp. 185-194, 2014.

[20] Y. Mu, G. Wang, and H.-Q. Yu, "Kinetic modeling of batch hydrogen production process by mixed anaerobic cultures," Bioresource Technology, vol. 97, no. 11, pp. 1302-1307, 2006. 

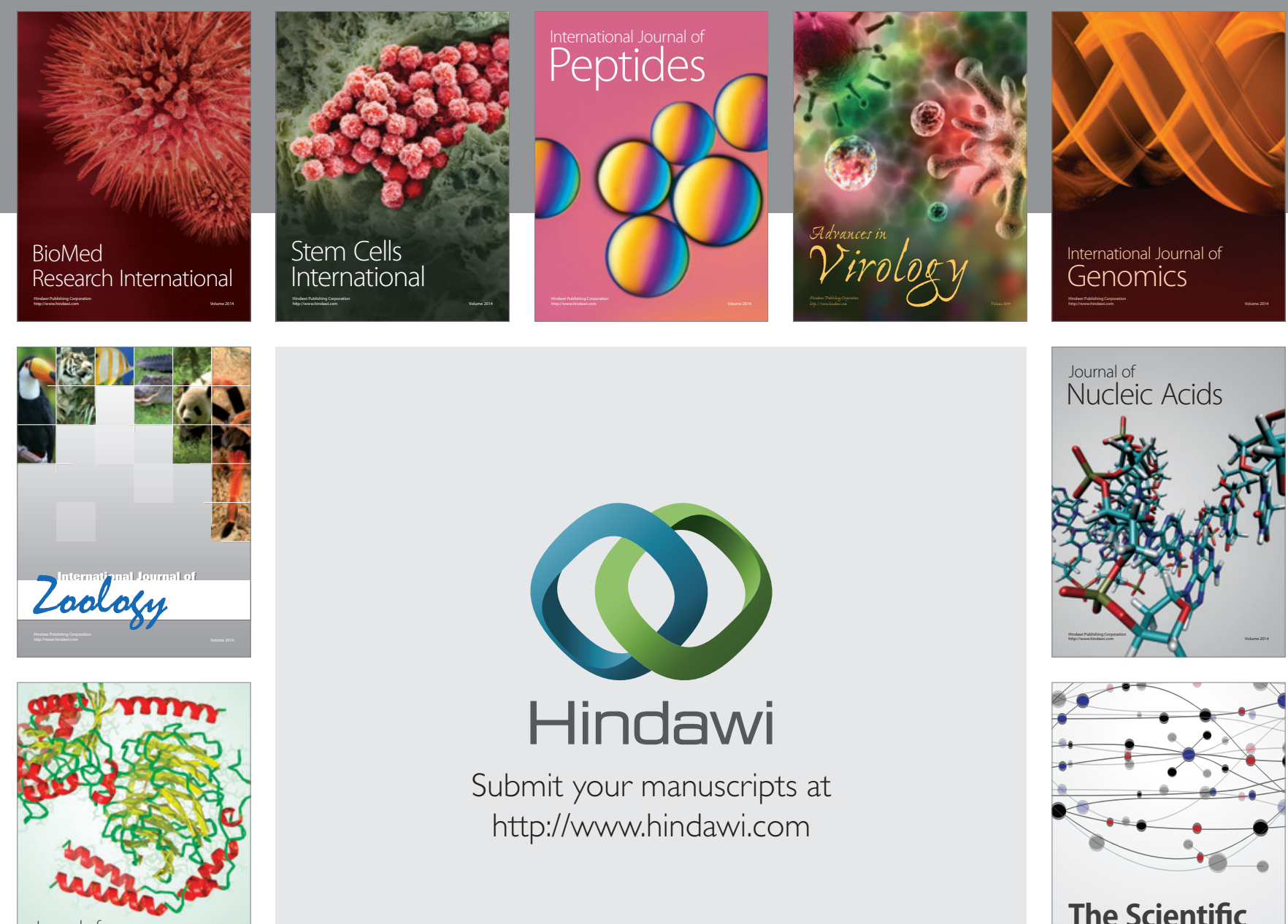

Submit your manuscripts at

http://www.hindawi.com

Journal of
Signal Transduction
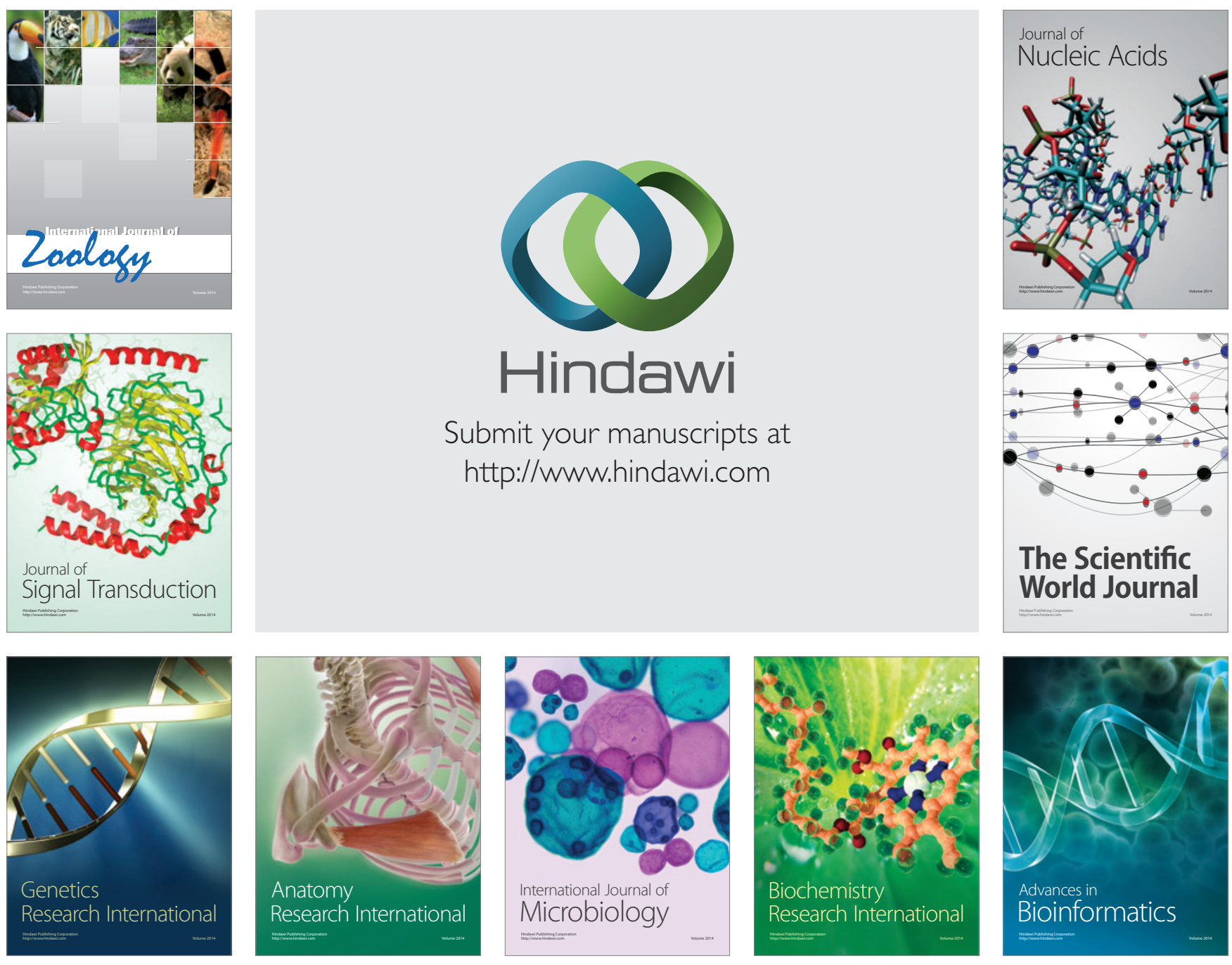

The Scientific World Journal
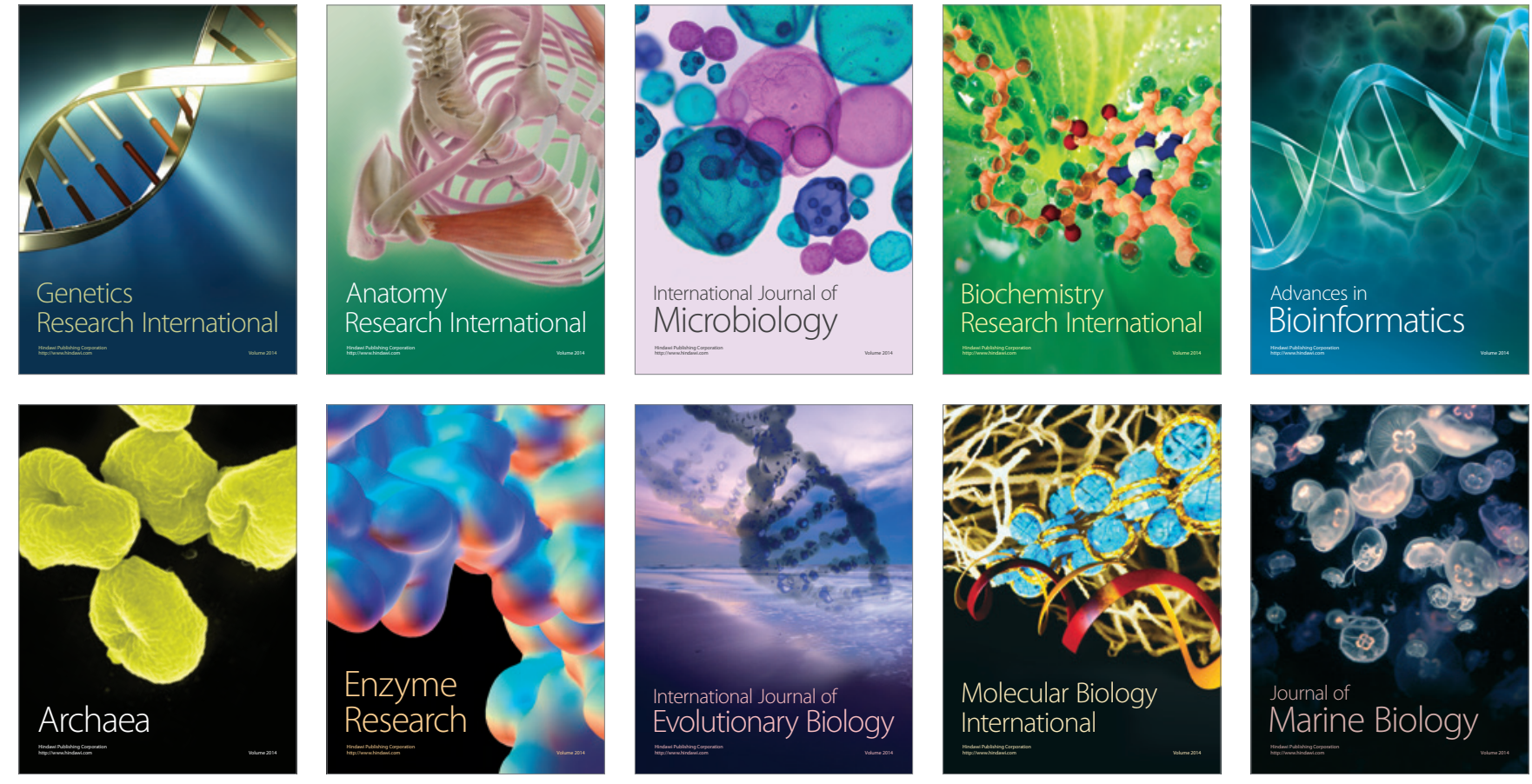